\title{
FORMULASI MINUMAN TEPUNG CACING TANAH (Lumbricus rubellus Hoffmeister) TERGANULASI DISERTAI UJI DAYA INGATNYA PADA MENCIT JANTAN
}

\author{
${ }^{1}$ Gita Cahya Eka Darma, ${ }^{2}$ Wulandari Putri Saraswati,${ }^{3}$ Esti Rachmawati Sadiyah \\ 1,2,3Program Studi Farmasi, Fakultas MIPA, Universitas Islam Bandung, Jawa Barat, Indonesia \\ email: ${ }^{1}$ wulanputs@gmail.com
}

\begin{abstract}
ABSTRAK
Protein merupakan suatu senyawa kimia yang penting bagi tubuh. Cacing tanah (Lumbricus rubellusHoffmeister) diketahui memiliki kandungan protein yang tinggi yang dapat dimanfaatkan sebagai protein alternatif. Penelitian ini bertujuan untuk mengetahui aktivitas tepung cacing tanah dalam meningkatkan daya ingat mencit (Mus musculus) serta formulasinya dalam bentuk sediaan minuman tepung cacing tanah tergranulasi. Pengujian aktivitas daya ingat dilakukan dengan menggunakan labirin Y dengan parameter pengamatan berupa waktu latensi (detik) dan jumlah kesalahan. Dosis optimum yang didapatkan dari uji daya ingat yaitu 325 $\mathrm{mg} / \mathrm{kg}$ BB yang setara dengan penggunaan dua kali sediaan yang mengandung $1,25 \mathrm{~g}$ tepung cacing tanah. Optimasi suspending agent dilakukan secara tunggal dan kombinasi dan didapatkan 3 formula kombinasi suspending agent paling baik dan dilanjutkan dengan proses granulasi. Dilakukan evaluasi pada formula berupa uji organoleptik, kelembaban, sifat alir, distribusi ukuran partikel, waktu rekonstitusi, waktu redispersi, volume sedimentasi, viskositas, stabilitas, uji hedonik dan analisis kuantitatif kadar protein. Berdasarkan evaluasi, satu formula optimum dipilih yaitu dengan kombinasi CMC-Na 0,5\%, Natrium Alginat 0,1\%, serbuk kunyit $3,75 \%$, gula putih $10 \%$, talk $3 \%$ dan Mg Stearat $1 \%$. Kadar protein yang terkandung dalam formula terbaik yaitu $26,03 \%$.
\end{abstract}

Kata kunci: Tepung cacing tanah, daya ingat, protein, suspending agent

\begin{abstract}
Protein is a chemical compound that is important for body. Earthworm (Lumbricus rubellus Hoffmeister) is known to have high protein content that can be used as alternative protein. This study aimed to determine the activity of earthworm flour in improving memory on mice (Mus musculus) and its formulation in the form of granulated earthworm flour beverage. Memory activity test was performed using $\mathrm{Y}$ labyrinth with observation parameter in the form of latency time (second) and number of errors. The optimum dose resulted from the memory test is 325 $\mathrm{mg} / \mathrm{kg} \mathrm{BB}$ which is equivalent to the use of two times the preparation containing $1.25 \mathrm{~g}$ of earthworm flour. Optimization of suspending agent was done singly and combination and obtained 3 formulae combination of best suspending agent and then continued to granulation proces. Formula evaluation conducted were organoleptic test, moisture, flow properties, particle size distribution, reconstitution time, redispersion time, sedimentation volume, viscosity, stability, hedonic test and quantitative analysis of protein content. Based of evaluation, one optimum formula was chosen which was, combination of $0,5 \% \mathrm{CMC}-\mathrm{Na}, 0,1 \%$ Sodium Alginate, 3,75\% turmeric powder, $10 \%$ white sugar, 3\% talk and Mg stearat 1\%. The protein contained in the best formula was $26.03 \%$.
\end{abstract}

Keywords: Earthworm flour, memory, protein, suspending agen 


\section{PENDAHULUAN}

Sumber daya alam adalah sesuatu yang berasal dari alam yang dapat digunakan untuk memenuhi kebutuhan manusia. Sumber daya alam di Indonesia sangat beragam. Indonesia merupakan negara dengan tingkat biodiversitas tertinggi kedua di dunia setelah Brazil (Hitipeuw, 2011). Salah satu sumber daya alam yang dapat dimanfaatkan berasal dari hewan. Hewan dapat dimanfaatkan selama tidak digunakan secara berlebihan. Salah satu hewan yang dapat dimanfaatkan adalah cacing tanah.

Cacing tanah (Lumbricus rubellus Hoffmeister) sudah tidak asing lagi di kalangan masyarakat Indonesia. Cacing tanah memiliki produktivitas yang lebih unggul dibanding cacing lain. Dalam setahun cacing tanah dapat menghasilkan sebanyak 106 kokon yang setiap kokon dapat menghasilkan 1-4 juvenil (anak cacing) (Auliah, 2008:38). Produktivitas yang tinggi dapat meningkatkan populasi cacing tanah. Cacing tanah memiliki kandungan protein yang tinggi yaitu 65,63\% (Damayanti, 2009:84). Kandungan protein yang tinggi dapat dimanfaatkan sebagai protein alternatif.

Protein merupakan suatu senyawa kimia yang sangat penting bagi tubuh karena selain berfungsi sebagai zat pembangun dan pengatur protein berfungsi juga untuk pertumbuhan sel dan fungsi otak serta perlindungan terhadap infeksi. Asam amino sebagai senyawa penyusun protein membentuk struktur otak dan zat penghantar rangsang (zat neurotransmitter) pada sambungan sel saraf atau sinaps.

Asam amino lain yang berperan pada sistem memori adalah glutamat. Menurut Carlson (2004 dalam Sadiyah, 2007:13), glutamat merupakan neurotransmiteryang paling umum ditemukan pada sistem saraf organisme tingkat tinggi maupun tingkat rendah. Glutamat merupakan neurotrasmiter yang berperan dalam proses potensiasis jangka panjang (Long Term Potentiation/LTP). LTP menghasilkan perubahan jangka panjang pada sinaps dan mendasari berbagai mekanisme yang terjadi dalam proses konsolidasi memori yaitu perubahan memori jangka pendek menjadi jangka panjang.

Memori adalah kemampuan seseorang untuk mengingat dengan sempurna hal-hal yang telah dialaminya pada masa lalu (AlInstanbuli, 2006:100). Upaya yang dapat dilakukan untuk meningkatkan memori salah satunya dengan mengkonsumsi makanan atau minuman yang bernutrisi dan mengandung protein. Beberapa contoh makanan dan minuman yang mengandung protein seperti, tahu, tempe, kacang, dan susu.

Permasalahan yang dapat disimpulkan adalah apakah minuman tepung cacing tanah tergranulasi dapat diterima dan dikonsumsi masyarakat umum dan menjadi sumber protein 
alternatif serta apakah memiliki aktivitas pada daya ingat. Penelitian ini bertujuan untuk membuat formula minuman tepung cacing tanah tergranulasi serta menguji aktivitas tepung cacing tanah terhadap daya ingat mencit jantan (Mus musculus L.). Penelitian ini diharapkan dapat mendorong pemanfaatan cacing tanah sebagai protein alternatif yang dapat meningkatkan daya ingat dan dapat diterima serta dikembangkan oleh masyarakat umum.

\section{METODE PENELITIAN}

\subsection{Alat dan bahan}

Timbangan analatik, alat-alat gelats. labirin Y, mesin tablet, Moisture Analytical Balance (Mettler Toledo, MJ33), Flow tester, Viskometer (Brookfield, RV DV I), granulometer.

\subsection{Metode}

Granul dibuat dengan menggunakan metode granulasi kering, pengujian daya ingat dengan metode labirin $\mathrm{Y}$, dan analisis kadar protein dengan metode Kjedhal.

\section{HASIL DAN PEMBAHASAN}

\subsection{Determinasi}

Cacing tanah (Lumbricus rubellus Hoffmeister) yang diperoleh dari CV. Bengkelden Agrobisnis, Cimahi, Jawa Barat, di determinasi di Museum Zoologi, Sekolah Ilmu dan Teknologi Hayati, Institut Teknologi Bandung yang bertujuan untuk memastikan kebenaran bahan yang digunakan pada penelitian ini. Hasil determinasi menunjukkan bahwa hewan yang digunakan adalah cacing tanah (Lumbricus rubellus Hoffmeister).

\subsection{Pengujian Daya Ingat}

Data terkait hasil pengujian daya ingat dapat dilihat pada gambar 1 .

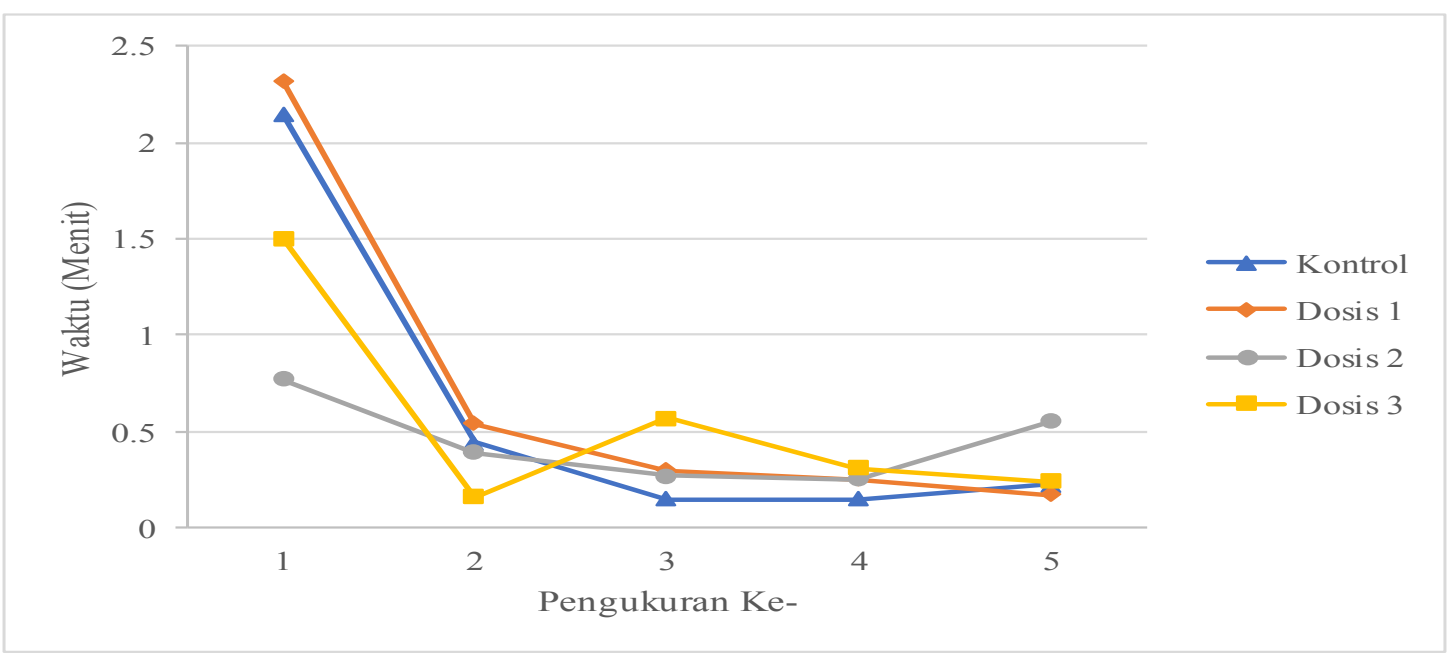

Gambar 1. Rata-rata waktu latensi untuk menemukan makanan 
Pada Gambar 1 dapat dilihat dari setiap kelompok umumnya mengalami penurunan waktu yaitu waktu yang dibutuhkan menjadi lebih cepat. Pada pengujian ke-5 waktu paling cepat ditunjukan pada kelompok dosis 1. Selain itu pada kelompok dosis 1 juga kecenderungan waktu latensi menurun dengan lebih cepat pada setiap pengujiannya dibandingkan kelompok lainnya. Di lain pihak terjadi fluktuasi pada kelompok dosis 3 yaitu terdapat peningkatan waktu latensi pada pengujian ke-3. Adapun selisih waktu pada pengujian ke-5 terhadap waktu ke-1 paling besar nilainya yaitu kelompok dosis 1 dengan waktu 2.15 menit.

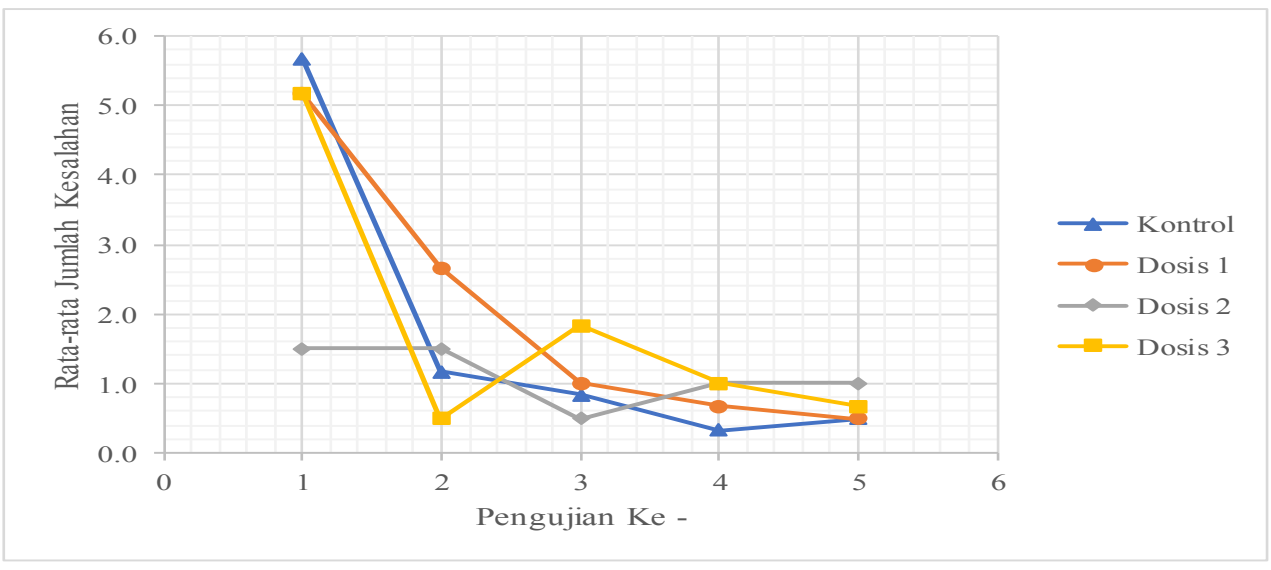

Gambar 2. Rata-rata jumlah kesalahan

Gambar 2 memperlihatkan bahwa dosis menggunakan suspending agent tunggal. 1 memiliki kecenderungan jumlah kesalahan yang semakin menurun dibandingkan kontrol maupun dosis lainnya. Parameter pengujian ini Namun hasil secara visual suspensi tidak stabil memiliki hasil yang serupa dengan pengamatan waktu dan diketahui bahwa semakin sedikit waktu latensinya maka semakin sedikit juga jumlah kesalahan yang dilakukan.

\subsection{Formulasi}

Pada tahapan formulasi dilakukan orientasi terlebih dahulu sebelum dilakukan proses granulasi. Orientasi ini bertujuan untuk mendapatkan suspending agent yang terbaik. Orientasi pertama dilakukan dengan yaitu ditunjukan dengan pemisahan atau terbentuknya endapan yang cepat setelah didiamkan 30 menit. PVP yang digunakan pada orientasi suspending agent tunggal tidak digunakan kembali karena pemisahan yang terjadi sangat cepat dan warna sediaan menjadi lebih gelap.

Dari ke-12 formula kombinasi suspending agent didapatkan 3 formula yang memiliki endapan yang sedikit. Formula terbaik dilanjutkan untuk pembuatan granul dengan metode granulasi kering. Metode granulasi kering dipilih karena tepung cacing tanah yang higroskopis sehingga akan membuat granul sulit kering jika dibuat dengan 
metode granulasi basah. Pada formula dilakukan stearat sebagai pelincir (lubrikan) yang membantu penambahan talk sebagai pelicin (glidant) dan mg- pada proses slugging saat membuat granul

Tabel 1 Formula minuman tepung cacing tanah tergranulasi

\begin{tabular}{|c|c|c|c|}
\hline \multirow{2}{*}{ Bahan $(\%)$} & \multicolumn{3}{|c|}{ Formula } \\
\hline & I & II & III \\
\hline Zat Aktif & 1,25 & 1,25 & 1,25 \\
\hline CMC-Na & 1 & 0,5 & 0,75 \\
\hline Na-Alginat & - & 0,1 & 0,1 \\
\hline PGA & 1 & - & - \\
\hline Serbuk kunyit & 3,75 & 3,75 & 3,75 \\
\hline Gula Putih & 10 & 10 & 10 \\
\hline Talk & 3 & 3 & 3 \\
\hline Mg Stearat & 1 & 1 & 1 \\
\hline
\end{tabular}

\subsection{Organoleptis}

Evaluasi organoleptis dilakukan untuk visual (Tabel 2) serta hasil organoleptis dalam mengetahui hasil granul yang dibuat secara bentuk larutan (Tabel 3).

Tabel 2 Organoleptis granul

\begin{tabular}{|c|c|c|c|}
\hline Pemerian & F1 & F2 & F3 \\
\hline Bentuk & Granul & Granul & Granul \\
\hline Warna & Kuning & Kuning & Kuning \\
\hline Bau & Kunyit & Kunyit & Kunyit \\
\hline Rasa & Sedikit manis & Sedikit manis & Sedikit manis \\
\hline
\end{tabular}

Tabel 3 Organoleptis larutan

\begin{tabular}{|c|c|c|c|}
\hline Pemerian & F1 & F2 & F3 \\
\hline Bentuk & Larutan & Larutan & Larutan \\
\hline Warna & Kuning & Kuning & Kuning \\
\hline Bau & Kunyit & Kunyit & Kunyit \\
\hline Ras a & Sedikit manis & Sedikit manis & Sedikit manis \\
\hline
\end{tabular}




\subsection{Uji Kelembaban}

Hasil evaluasi (Tabel 4)memenuhi syarat jika

Uji kelembaban ditunjukan untuk kelembaban 1-3\% (Depkes RI, 1995: 4-6).

melihat kadar air yang terkandung pada granul.

Tabel 4 Uji kelembaban

\begin{tabular}{|c|c|c|c|}
\hline \multirow{2}{*}{ Formula } & \multicolumn{3}{|c|}{ Kadar Air (\%) } \\
\hline & F1 & F2 & $\mathbf{F 3}$ \\
\hline 1 & 3.00 & 3.56 & 2.96 \\
\hline 2 & 4.01 & 3.37 & 2.65 \\
\hline 3 & 3.45 & 4.20 & 3.00 \\
\hline Rata-Rata & 3.49 & 3.71 & 2.87 \\
\hline
\end{tabular}

\subsection{Uji Sifat Alir dan Sudut Baring}

Uji sifat alir dan sudut baring merupakan salah satu parameter menentukan hasil granul baik atau tidak. Sifat alir sendiri pada proses pembuatan tablet bertujuan untuk melihat apakah granul akan mudah mengalir pada proses pencetakan. Pada penelitian ini digunakan untuk melihat apakah granul akan mudah dikeluarkan dari kemasannya. Granul yang baik akan mengalir dengan waktu 100 gram/10 detik. Berdasarkan Tabel 5 waktu yang diperlukan untuk mengalirkan 30 gram granul memberikan hasil waktu dibawah 3 detik yang menunjukkan bahwa granul mudah mengalir. Sudut baring yaitu sudut yang terjadi antara timbunan partikel bentuk kerucut dengan bidang horizontal. Dapat dilihat pada Tabel 6 sudut baring yang terbentuk berada dibawah $30^{\circ}$ yang menyatakan bahwa granul sangat mudah mengalir

Tabel 5 Uji sifat alir

\begin{tabular}{|c|c|c|c|}
\hline \multirow{2}{*}{ Formula } & \multicolumn{3}{|c|}{ Sifat Alir (Detik) } \\
\hline & F1 & F2 & F3 \\
\hline 1 & 1.57 & 1.69 & 1.25 \\
\hline 2 & 1.48 & 1.69 & 1.41 \\
\hline 3 & 1.33 & 1.84 & 1.56 \\
\hline Rata-Rata & 1.46 & 1.74 & 1.41 \\
\hline
\end{tabular}


Tabel 6 Uji sudut baring

\begin{tabular}{|c|c|c|c|}
\hline \multirow{2}{*}{ Formula } & \multicolumn{3}{|c|}{ Sudut Baring $\left({ }^{\circ}\right)$} \\
\hline & F1 & F2 & F3 \\
\hline 1 & 20.30 & 22.978 & 21.80 \\
\hline 2 & 23.461 & 21.999 & 24.227 \\
\hline 3 & 20.556 & 24.61 & 23.52 \\
\hline Rata-Rata & 21.44 & 23.195 & 23.18 \\
\hline
\end{tabular}

\subsection{Uji distribusi ukuran partikel}

Uji distribusi ukuran partikel bertujuan untuk melihat ukuran dan ketersebaran granul.Tabel 7 memperlihatkan ketiga formula memiliki presentase ketersebaran granul paling banyak berada pada mesh 20 . Namun pada mesh 120 masih menunjukkan presentase yang besar dan masih cukup banyak berbentuk serbuk. Hal ini karena memang pada saat proses cukup sulit untuk membuat granul dan hasil granul yang diperoleh cukup rapuh. Seharusnya ketersebaran granul yang baik hendaknya ada pada rentang lebih dari $40 \%$ pada ayakan mesh nomor 16 dan 20. Pada mesh 20 memiliki ukuran partikel $850 \mu \mathrm{m}$ (Ansel et al., 2011:185).

Tabel 7 Hasil rataan evaluasi granulometri

\begin{tabular}{|c|c|c|c|c|c|c|c|c|}
\hline \multirow{2}{*}{ Formula } & \multirow{2}{*}{ Bobot (g) } & \multicolumn{7}{|c|}{ Presentase bobot ( $\%$ ) } \\
\hline & & Mesh 16 & Mesh 20 & Mesh 40 & Mesh 60 & Mesh 80 & Mesh 100 & Mesh 120 \\
\hline 1 & 50 & 12.904 & 32.798 & 7.244 & 5.824 & 7.438 & 7.95 & 23.442 \\
\hline 2 & 50 & 6.308 & 28.562 & 10.06 & 5.68 & 10.32 & 13.738 & 20.528 \\
\hline 3 & 50 & 19.73 & 27.206 & 11.688 & 2.234 & 8.36 & 7.5 & 19.66 \\
\hline
\end{tabular}

3.8 Waktu Rekonstitusi dan Waktu diperlukan untuk mendispersikan granul Redispersi

Waktu rekonstitusi yang baik yaitu kurang dari

Waktu rekonstitusi adalah waktu yang 30 detik. Tabel 8 memperlihatkan waktu 
rekonstitusi yang diperlukan pada ketiga kembali dengan cara dikocok dan waktu yang formula kurang dari 30 detik sehingga diperlukan kurang dari 30 detik. Berdasarkan memenuhi syarat.

Waktu redispersi adalah waktu yang redispersi kurang dari 30 detik. diperlukan suspensi untuk dapat terdispersi

Tabel 8 Waktu rekonstitusi

\begin{tabular}{|c|c|}
\hline Formula & Waktu Rekons titusi (detik) \\
\hline 1 & 10.17 \\
\hline 2 & 9.48 \\
\hline 3 & 9.37 \\
\hline
\end{tabular}

Tabel 9 Waktu redispersi

\begin{tabular}{|c|c|}
\hline Formula & Waktu Redispersi (detik) \\
\hline 1 & 4.21 \\
\hline 2 & 2.48 \\
\hline 3 & 3.16 \\
\hline
\end{tabular}

3.9 Volume Sedimentasi dan Uji kekentalan dari sediaan. Pada uji viskositas

\section{Viskositas}

Volume sedimentasi adalah endapan yang terbentuk pada sediaan suspensi setelah didiamkan dalam waktu tertentu. Berdasarkan Tabel 10 dapat diketahui bahwa endapan paling sedikit dihasilkan yaitu pada formula 2 . Uji viskositas dilakukan untuk mengetahui spindel yang digunakan ada spindel nomer 61 karena memiliki nilai persentase (\%) yang terbaca paling tinggi. Bedasarkan Tabel 11 dapat diketahui bahwa yang memiliki cps pada rpm 100 terendah adalah formula 2 yang menunjukkan memiliki viskositas yang paling rendah. 
Tabel 10 Volume sedimentasi

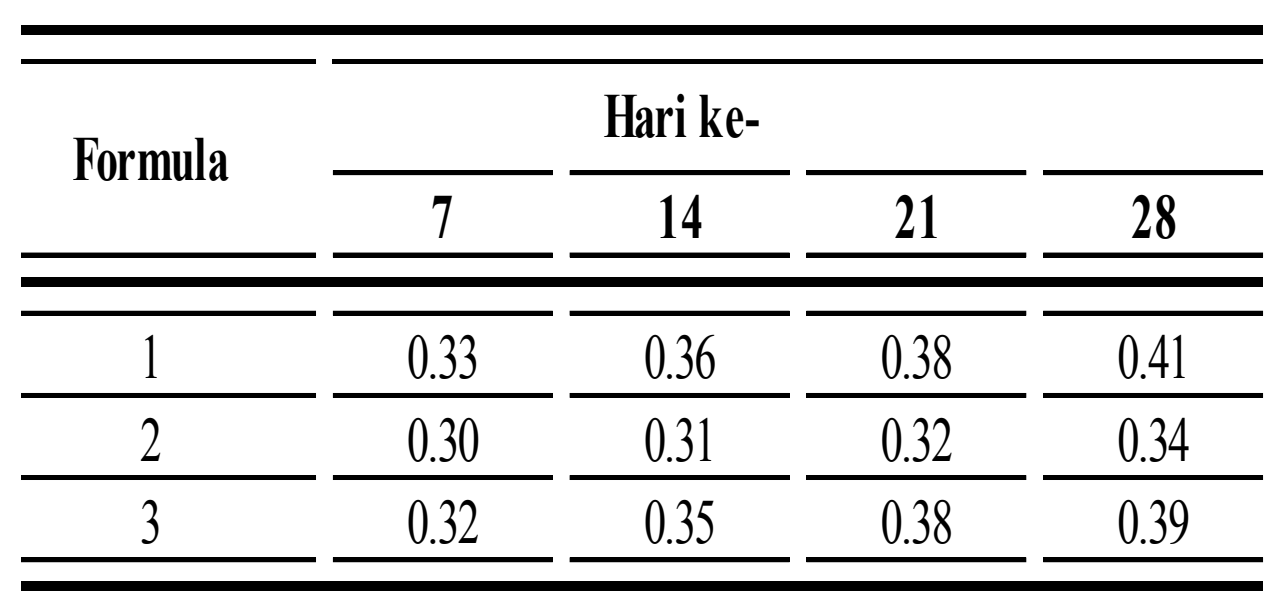

Tabel 11 Viskositas

\begin{tabular}{|c|c|}
\hline Formula & Cps \\
\hline 1 & 6,4 \\
\hline 2 & 5,12 \\
\hline 3 & 7,68 \\
\hline
\end{tabular}

\subsection{Uji hedonik}

Uji hedonik dilakukan untuk melihat

tingkat kesukaan konsumen. Berdasarkan

Gambar 3 dapat dilihat bahwa tidak ada

perbedaan nilai yang diberikan panelis pada

parameter bau, rasa dan warna dari sediaan.
Seluruh panelis yang melakukan uji hedonik tidak ada satupun yang memberikan nilai suka baik dari warna, bau, dan juga rasa, dan dapat diartikan bahwa sediaan masih belum dapat diterima baik oleh konsumen. 
Formula Minuman Tepung Cacing Tanah....

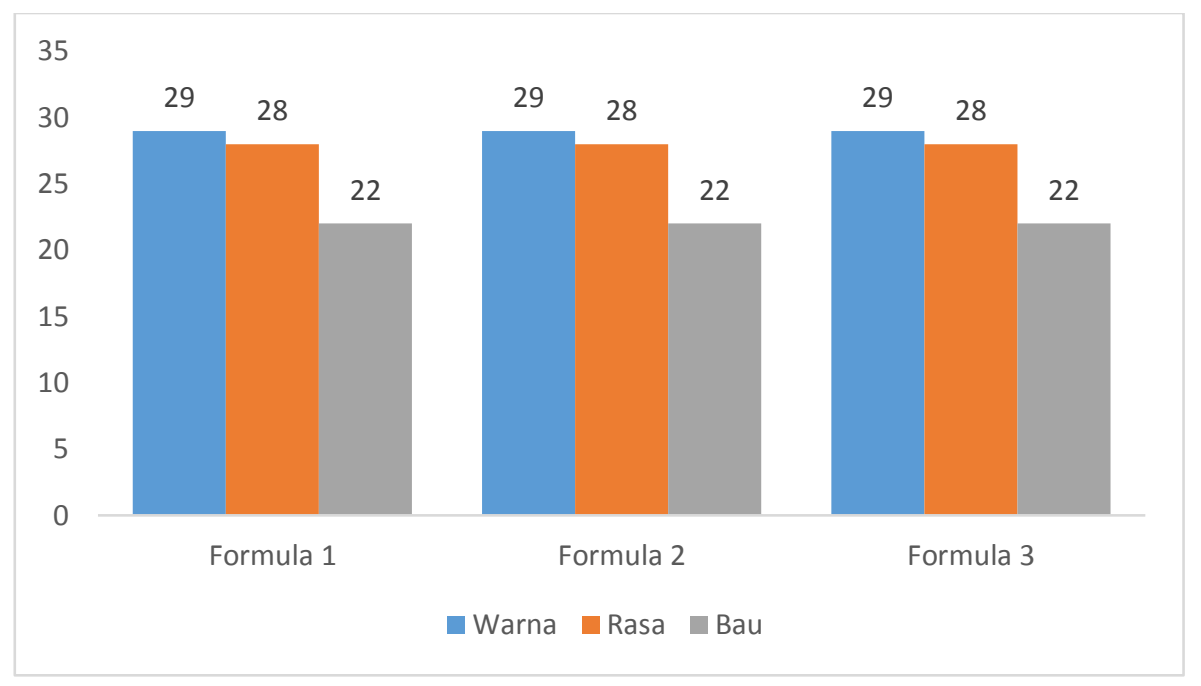

Gambar 3 Hasil uji hedonik

\subsection{Uji Stabilitas}

Uji stabilitas dilakukan untuk melihat kestabilan sediaan setelah didiamkan selama 28 hari pada suhu $40^{\circ} \mathrm{C}$. Pengamatan dilakukan meliputi organoleptis sediaan yaitu bentuk, warna, dan bau dapat dilihat pada Tabel 12 sediaan masih memiliki bentuk organoleptis yang sama seperti awal pengamatan.

Tabel 12 Organoleptis uji stabilitas

\begin{tabular}{|c|c|c|c|}
\hline Pemerian & F1 & F2 & F3 \\
\hline Bentuk & Granul & Granul & Granul \\
\hline Warna & Kuning & Kuning & Kuning \\
\hline Bau & Kunyit & Kunyit & Kunyit \\
\hline
\end{tabular}

\subsection{Analisis Kuantitatif Protein}

Analisis kuantitatif protein bertujuan untuk mengetahui kadar protein yang terkandung dalam sediaan. Analisis kuantitatif protein dilakukan dengan menggunakan metode Kjedhal yaitu mengukur kadar nitrogen yang tergandung dalam sediaan. Dari hasil pengujian didapatkan kadar protein sebesar pada formula tanpa zat aktif sebesar $25,84 \%$ dan pada formula yang menggunakan zat aktif $26,03 \%$.

\section{KESIMPULAN DAN SARAN}

\subsection{Kesimpulan}

Tepung cacing tanah (Lumbricus rubellus Hoffmeister) memiliki aktivitas meningkatkan daya ingat mencit jantan (Mus musculus) pada konsentrasi $325 \mathrm{mg} / \mathrm{kg}$ BB yang setara dengan penggunaan 2 kali sediaan yang mengandung $1,25 \mathrm{~g}$ tepung cacing tanah. Formulasi minuman tepung cacing tanah 
tergranulasi yang paling stabil adalah formula

2 dengan menggunakan suspending agent

CMC-Na dan natrium alginat. Kadar protein

yang terkandung dalam formula terbaik adalah $26,03 \%$.

\subsection{Saran}

Perlu dilakukan formulasi kembali dengan optimasi suspending agent untuk mendapatkan sediaan yang lebih stabil dan memperbaiki rasa agar dapat diterima serta dikonsumsi masyarakat umum.

\section{DAFTAR PUSTAKA}

Al-Instabuli, M.M., 2006. Parenting Guide, Dialog Imajiner Tentang Cara Mendidik Anak Berdasarkan Al-Qur'an, As-Sunah dan Psikologi. Hikmah Populer, Jakarta.

Ansel, H., Allen, L., Popovic, N., 2011. Ansel's Pharmaceutical Dosage Forms and Drug Delivery Systems Ninth Edition. Lippincott Williams \& Wilkins, a Wolters Kluwer business, Philadelphia

Auliah, Army., 2008. Pengaruh Umur Terhadap Keragaman Kandungan Asam Amino Cacing Tanah Lumbricus rubellus. Jurnal Chemica, 9(2)
Damayanti, E., H. Julendra dan A. Sofyan., 2009. Pemanfaatan Tepung Cacing Tanah (Lumbricus rubellus) sebagai Agensia AntiPullorum dalam Imbuhan Pakan Ayam Broiler. JITV, 14(2)

Departemen Kesehatan Republik Indonesia., 1995. Farmakope Indonesia, Edisi IV. Direktorat Jenderal Pengawasan Obat Dan Makanan, Jakarta

Hitipeuw, J., 2011. Indonesia, The World's Second Mega Biodiversity Country, Kompas 16 Mei 2011

Istiqomah, L., A. Sofyan., E. Damayanti dan H. Julendra., 2009. Amino Acid Profile of Earthworm and Earthworm Meal (Lumbricus rubellus) For Animal Feedstuff. J. Indonesia Trop.Anim.Agric 34(4).

Nash, R.A., 1985. Pharmaceutical Dosage Forms, Disperse System Vol 2. St. John's Universtity, New York.

Palungkun, R. 2010. Usaha Ternak Cacing Tanah Lumbricus rubellus. Penebar Swadaya, Jakarta

Sadiyah, E. R. 2007. Pengaruh Ekstrak Kasar Daun Pepaya (Carica papaya L.) Terhadap Kemampuan Belajar Pada Tikus (Rattus norvegieus Berkenhout) Wistar Jantan Lepas Sapih [Tesis], Program Studi Biologi Sekolah Ilmu dan Teknologi Hayati, Institut Teknologi Bandung.

Santoso, H., dan I. Andar., 2009. Memamahi krisis lanjut usia: uraian medis dan pedagogis-pastoral. Gunung Mulia, Jakarta 